

\section{The $13^{\text {th }}$ International Conference on Global Research and Education}

INTER ACADEMIA 2014

\section{Digest}

September 10-12, 2014

Riga, LATVIA 


\section{Editorial Board:}

Arturs Medvids, Dr.habil.phys., Riga Technical University, Latvia Andris Ozols, Dr.habil.phys., Riga Technical University, Latvia Gundars Mezinskis, Dr.habil.sc.ing., Riga Technical University, Latvia Talivaldis Puritis, Dr.habil.phys., Riga Technical University, Latvia Steponas Asmontas, Dr. Sci., Semiconductor Physics Institute, Lithuania

Pavels Onufrijevs, Dr. phys., Riga Technical University, Latvia Igor Dmitruk, Dr.Sci., Kyiv Taras Shevchenko University, Ukraine Jevgenijs Kaupužs, Dr.phys., University of Liepaja, Latvia Karlis Gross, Dr.phil., Riga Technical University, Latvia

\section{Editorial Board Address:}

Inter-Academia 2014

Institute of Technical Physics

Faculty of Materials Science and Applied Chemistry

Riga Technical University

3 Paula Valdena St., Riga, LV-1048, LATVIA

Phone: +37167089455

Fax: +37167089074

e-mail: ia2014@rtu.Iv

C) Riga Technical University, 2014 


\section{Organized by:}
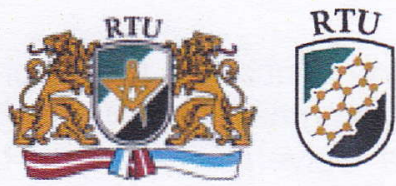

MATERIĀLZINĀTNES

UN LIETIŠKKĀS KৃIMIJAS

FAKULTĀTE

Riga Technical University, Faculty of Materials Science and Applied Chemistry, Institute of Technical Physics, Research Laboratory of Semiconductor Physics

In co-operation with:

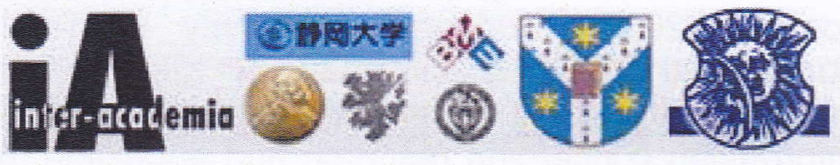

\section{Inter-Academia Community:}

Shizuoka University, Japan

Comenius University, Slovakia

Budapest University of Technology and Economics, Hungary

Warsaw University of Technology, Poland

Wuppertal University, Germany

Alexandru loan Cuza University, Romania

Gomel State University, Belarus

Riga Technical University, Latvia

Masaryk University, Czech Republic

Sofia University, Bulgaria

Óbuda University, Hungary

Taras Shevchenko National University of Kyiv, Ukraine

St. Petersburg State Institute of Technology, Russia

\section{Shizuoka University (JAPAN).}

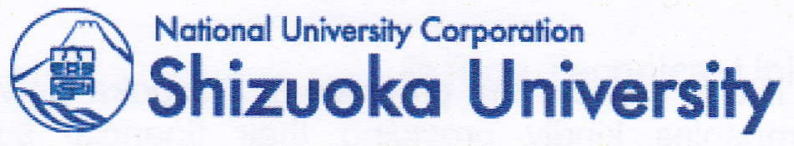

3. Riga-based International Society of Applied Optics (LATVIA).

4. Latvian Optical Society (EOS branch).

\section{LOS}

LATVIAN OPTICAL SOCIETY 


\section{Honorary Committee:}

Leonids Ribickis, Riga Technical University, Latvia

Yukihiro Ito, Shizuoka University, Japan

Jan Szmidt, Warsaw University of Technology, Poland

Vasile Isan, Alexandru loan Cuza University, Romania

Gábor Péceli, Budapest University of Technology and Economics, Hungary

Lambert T. Koch, University of Wuppertal, Germany

Karol Mičieta, Comenius University, Slovakia

Mikuláš Bek, Masaryk University, Czech Republic

Aleksandr V. Rogachev, Gomel State University, Belarus

Janos Fodor, Óbuda University, Hungary

Leonid V. Hubersky, Taras Shevchenko National University of Kyiv,

Ukraine

Ivan Ilchev, Sofia University, Bulgaria

\section{General Chair:}

Arturs Medvids, Riga Technical University, Latvia

\section{Co-Chair:}

Talis Juhna, Riga Technical University, Latvia

\section{Executive Committee:}

Annamária R. Várkonyi-Kóczy (Óbuda University, Hungary)

Arturs Medvids (Riga Technical University, Latvia)

Dariusz Korzec (University of Wuppertal, Germany)

Dumitru Luca (Alexandru loan Cuza University, Romania)

Evgenia Benova (Sofia University, Bulgaria)

Gheorghe Popa (Alexandru Ioan Cuza University, Romania)

Hidenori Mimura (Shizuoka University, Japan)

Hiroshi Mizuta (University of Southampton, England)

Jürgen Engeman (University of Wuppertal, Germany)

Kenji Murakami (Shizuoka University, Japan)

Leonid Poperenko (Taras Shevchenko National University of Kyiv, Ukraine)

Leszek Kudla (Warsaw University of Technology, Poland)

Lucel Sirghi (Alexandru loan Cuza University, Romania)

Masaaki Nagatsu (Shizuoka University, Japan)

Masashi Kando (Prof. Emeritus-Shizuoka University, Japan)

Michiharu Tabe (Shizuoka University, Japan)

Nicoleta Dumitrascu (Alexandru loan Cuza University, Romania) 
Nobuyuki Araki (Prof. Emeritus-Shizuoka University, Japan)

Noriko Matsuda (Shizuoka University, Japan)

Péter Korondi (Budapest University of Technology and Economics,

Hungary)

Ryszard Jablonski (Warsaw University of Technology, Poland)

Sergei Khakhomov (Gomel State University, Belarus)

Stefan Matejcik (Comenius University, Slovakia)

Valdis Kokars (Riga Technical University, Latvia)

\section{Local Organizing Committee:}

Arturs Medvids

Iveta Medvida (secretary)

Pavels Onufrijevs

Edvins Dauksta

llona Pavlovska

Liga Grase

\section{Programme Committee:}

Andris Ozols (Chairman of Programme Committee, Riga Technical University, Latvia)

Andris Sternbergs (University of Latvia, Latvia)

Dagnija Loca (Riga Technical University, Latvia)

Enn Mellikov (Tallinn University of Technology, Estonia)

Gundars Mezinskis (Riga Technical University, Latvia)

Igor Dmitruk (Kyiv Taras Shevchenko University, Ukraine)

Jevgenijs Kaupužs (University of Liepaja, Latvia)

Jurijs Dehtjars (Riga Technical University, Latvia)

Karlis Gross (Riga Technical University, Latvia)

Maris Knite (Riga Technical University, Latvia)

Steponas Asmontas (State research institute Center for Physical Sciences and Technology, Lithuania)

Talivaldis Puritis (Riga Technical University, Latvia) 


\title{
The New Type of Knitted Resistive Fabric and Its Application
}

\author{
A.OKS ${ }^{1}$, A. KATASHEV ${ }^{1}$, J. LITVAK ${ }^{2}$ \\ ${ }^{1}$ Riga Technical University, "2Politeks LTD"
}

\section{Summary}

The developed knitted resistive fabric is related to the production of "smart textiles", integrated in garments for health monitoring. This fabric is produced from conductive resistive, nonconductive regular and nonconductive elastomeric yarns. Elastomeric yarn is the base yarn and is knitted in the whole fabric, but isolating and resistive yarns (functional yarns) are knitted separately from each other, but together with the base yarn in a specific sequence. The proposed knitted resistive fabric has high sensitivity to strain deformation and can be used as a sensing element to control deformation of the human body parts, joint motion, respiration, etc.

\section{Introduction}

Control systems with flexible sensing elements, made of textile fabrics with conductive threads, find wide range of healthcare applications, including health monitoring and rehabilitation [1-3]. Such systems can be embedded directly in garments and are wearable without any discomfort for the user. One of the types of such sensing elements includes sensors, knitted with conductive yarns [4-5]. Ohmic resistivity of such sensors depends on the deformation of the knitted sensing element. One of weak points of the known knitted sensors is their comparatively low sensitivity. The present paper demonstrates knitted sensing elements that have increased sensitivity that widen the area of possible applications.

\section{Knitting technology and the properties of the knitted structure}

The proposed sensing element (knitted resistive fabric) is knitted from conductive resistive and nonconductive isolating yarns together with elastomeric nonconductive thread. Elastomeric thread is the base, but isolating and resistive yarns are functional yarns. Fabric is knitted using plain stitch where courses are formed alternately form isolating and resistive. Due to compressive effect, caused by base elastomeric thread, neighboring courses, formed by conductive yarn, contact each other even in the unloaded sensing element. Such unloaded sensing element has initial resistance $R_{e}$ which can be defined by Holme's contact theory [6]. Application of strain load in weft direction causes gradual decrease of contact pressure between neighboring threads and, due to this, partial or complete interruption of electrical contact between conductive courses. Such behavior of the knitted structure leads to gradual increase of equivalent resistance $R_{e}$. For some cases, resistance of the stretched fabric tends to infinity. 
Experiments demonstrated comparatively high sensitivity of the fabric resistivity to strain deformation (Fig.1). The sensitivity depends on the properties of resistive yarn, width of conductive courses, thickness of isolating yarn. By variation of these parameters, one may control the properties of the sensing element. Unfortunately, notable hysteresis has to be taken into account when developing fabric sensor-based measurement system.

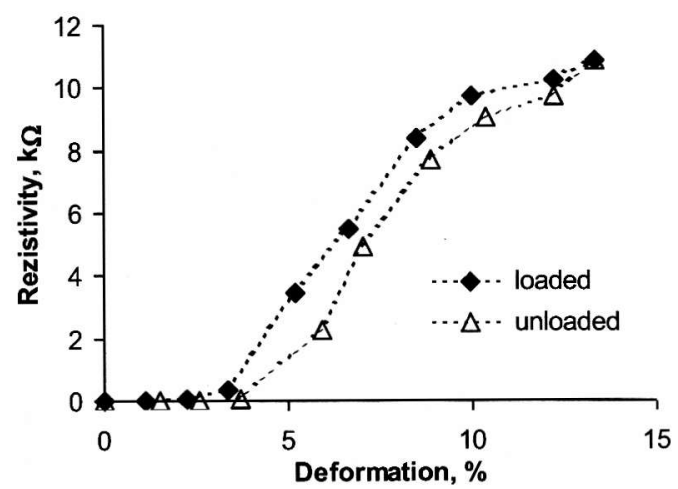

Fig. 1. Typical dependence of the knitted fabric resistivity on the relative deformation (10 cm long and $10 \mathrm{~cm}$ wide piece was used)

\section{Conclusion}

The proposed fabric demonstrates good sensitivity and may be used for smart textile strain sensors manufacturing.

\section{References}

[1] Hoffmann, T.; Eilebrecht, B.; Leonhardt, S. Respiratory Monitoring System on the Basis of Capacitive Textile Force Sensors. IEEE Sens. J. 2011, 11, pages $1112-1119$.

[2]Pacelli, M.; Loriga, G.; Paradiso, R. Flat knitted sensors for respiration monitoring. In Proceedings of the IEEE International Symposium on Industrial Electronics (ISIE), Vigo, Spain, 4-7 June 2007.

[3]Mattmann, C.; Amft, O.; Harms, H.; Troster, G.; Clemens, F. Recognizing upper body postures using textile strain sensors. In Proceedings of the 11th IEEE International Symposium on Wearable Computers, Boston, MA, 11-13 October 2007.

[4]Wijesiriwardana, R.; Dias, T.; Mukhopadhyay, S. Resistive fibre-meshed transducers. In Proceedings of the Seventh IEEE International Symposium on Wearable Computers (ISWC'03), New York, NY, USA, 21-23 October 2003.

[5] Atalay, O.; Kennon, W.; Husain, M. Textile-Based Weft Knitted Strain Sensors: Effect of Fabric Parameters on Sensor Properties. Sensors 2013, 13, pages $11114-11127$.

[6] Holm, R. Electric Contacts: Theory and Applications, 4th ed.; SpringerVerlag: New York, NY, USA, 1967. 